\title{
EXPERIMENTAL STUDY ON THE BEHAVIOUR OF CONCRETE INFILED LIGHT GAUGE STEEL BEAMS
}

\author{
Naveen $\mathbf{R} \mathbf{K}^{\mathbf{1}}$, Valsaipe $\mathbf{T}^{\mathbf{2}}$ \\ ${ }^{I}$ M.Tech. Sri Venkateshwara College of Engineering, Bengaluru, Karnataka. India. \\ navi1114@gmail.com, \\ ${ }^{2}$ professor, Faculty of Civil Engineering, MS Ramaiah University Of Applied Science, Bengaluru, Karnataka, India. \\ valsaipe@yahoo.co.in,
}

\begin{abstract}
The flexural behaviour of thin walled steel beams with normal concrete of grade M30 and light weight epoxy polystyrene concrete as infill are investigated by making an experimental study supported by analytical predictions. Totally 12 specimens are tested. Six beams infilled with normal concrete and six beams infilled with light weight concrete in each beam of two different cross section dimensions and for each cross section with three different thicknesses the beams are fabricated. The beams tested up to failure by simply supporting the beams having effective span of $1800 \mathrm{~mm}$ under two point loading. From the study, it is found that strength to weight ratios of sections increases with increase in thickness of steel and the moment carrying capacity of the beam increases as the grade of the infilled concrete increases. The ductility index and rotation capacity are observed to be higher in composite sections infilled with light weight epoxy polystyrene concrete.
\end{abstract}

Keywords: Cold Formed Steel, Epoxy Polystyrene Concrete, Flexural Behaviour, Infilled Beams, Light Weight Concrete.

\section{INTRODUCTION}

Composite structure is a combination of two or more different materials rigidly connected together to act as one unit and hence to have a composite action. Each material will be having their own defined role in the composite structure.

\subsection{Cold Formed Steel (CFS)}

Cold formed steel is a type of steel manufactured, processed, fabricated by processing the steel at ambient temperature. Cold rolled sheets (Plate 1) are widely used in all fields of construction industry, mechanical industry, electrical industry etc. The manufacturing process of the cold formed steel products will be done at room temperatures and manufacturing process includes pressing and rolling. Cold formed steel sheets or strips which are generally used in construction industry ranges from $0.3 \mathrm{~mm}$ to $6.3 \mathrm{~mm}$. Cold formed Steel is used in various industries such as bridges, car bodies, grain storage bins, railway coaches, transmission towers, light commercial building construction instead of wood framing, window panels, door panels etc. Due to the virtue of cold working of metal, we find some of the changes in mechanical properties of the metal sheets. When the steel section is formed at ambient temperature condition from the flat strips or sheets, the yield strength and to a lesser extent the ultimate strength increases, especially in the bends of the section.[3]

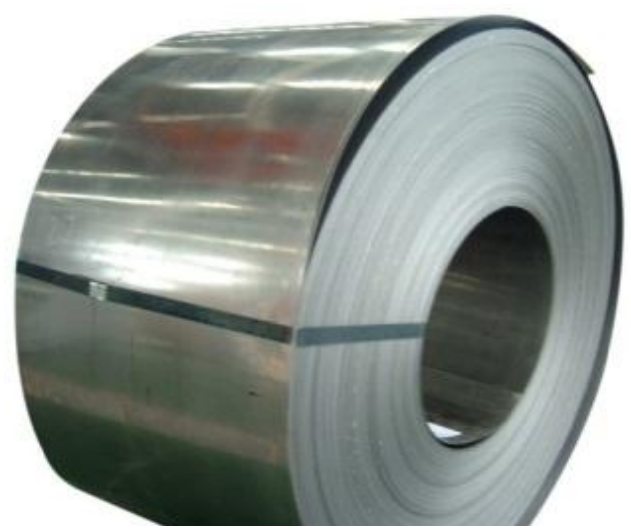

Plate1: 1Cold Formed Steel Sheets and Rollers

\subsection{Shear Connectors}

Shear connectors are designed to transfer the longitudinal shear along the interface and also to help in resisting the separation of concrete particles from the steel beams at the interface.

\subsection{Expanded polystyrene beads (eps)}

Polystyrene is a synthetic aromatic polymer which is made from monomer styrene and it can be a solid or foamed shown in Plate 2. Polystyrene is a long chain hydrocarbon, where alternating carbon centres are attached to phenyl group (Figure 1). It has the chemical elements of Carbon and Hydrogen. 
<smiles>CCCCCC(C)(C)C</smiles>

Figure 1.Chemical structure of EPS beads

Expanded polystyrene is a Rigid Cellular plastic which was originally invented by Germans in 1950's. It is durable, light in weight, protective insulating, easily bonded, versatile, easily recyclable. Expanded polystyrene beads are often used as packaging material. This leads to a large amount of waste which is not Bio-degradable material. So, this waste material could be granulated and used as light weight Aggregate for concrete.

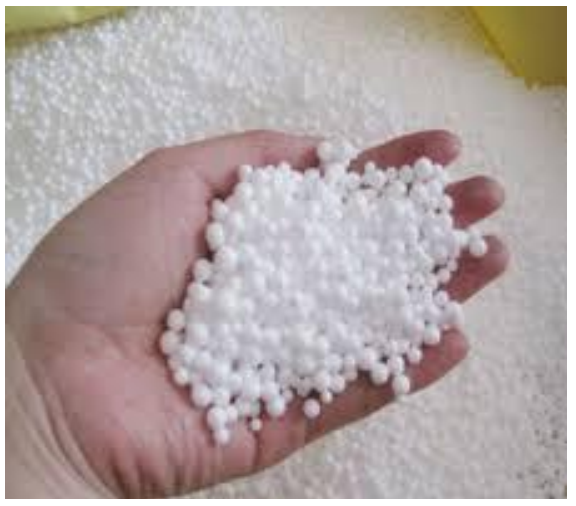

Plate 2: EPS beads

\subsection{Objective And Scope Of The Work}

The objective of the study is "To study flexural behaviour of cold formed steel channel sections infilled with different grades of concrete". Scope of the present work consists of an experimental study on light gauge steel sections infilled with concrete. Studies are carried out using two different grades of concrete as infill and two different cross sectional dimensions are used for the beams. Three different thicknesses of steel sheets are considered for the study.

\section{THEORETICAL STUDY}

Rigid plastic theory is adopted in developing the equations for calculating the moment carrying capacity of composite beams [15]. Consider a simply supported beam with channel section infilled with concrete and lip present in compression side. The flexural strength of the composite beams can be found by considering the distribution of forces in the concrete and steel sections

Let $\mathrm{d}=$ Depth of section, $l=$ Lip length, $\mathrm{b}=$ width of section, $P_{c}=$ force due to concrete, $P_{B}=$ Bond force, $b_{c}=$ width of the concrete, $N_{c}$ and $N_{S}=$ Distance of neutral axis from the extreme compression face for concrete and steel respectively, $\mathrm{M}=$ Moment carrying capacity of composite beams, $P_{t}=$ force at top flange, ${ }^{\gamma}=$ Reduction factor, $P_{w t}=$ force at web portion above neutral axis, $P_{w b}=$ force at web portion below neutral axis, $P_{b}=$ Force at bottom flange, $\mathrm{b}=$ Distance of bond force from compression face, $\mathrm{t}=$ thickness of steel, $f_{y}=$ yield stress of the steel, $f_{c k}=$ characteristic compressive strength of concrete. Calculation of moment carrying capacity and theoretical loads are shown in Appendix A

$f_{c}^{\prime}=0.8 f_{c k}$

Reduction factor $=0.85-0.007\left(f^{\prime}{ }_{c}-28\right)$

For full interaction between steel and concrete,

$$
\begin{gathered}
\mathrm{N}=\frac{t f_{y}\left(2 d+b_{c}-2 l\right)-P_{B}}{4 t f_{y}} \\
P_{B}=\frac{0.85 \gamma f_{c}^{\prime} b_{c} t f_{y}\left(2 d+b_{c}-2 l\right)}{0.85 \gamma f_{c}^{\prime} b_{c}+4 t f_{y}} \\
\mathrm{M}=t f_{y}\left(d^{2}+d b_{c}-2 N^{2}\right)-0.425 \gamma^{2} N^{2} f_{c}^{\prime} b_{c}-t^{2} f_{y} l
\end{gathered}
$$$$
N_{c}=N_{s}=N
$$

\section{EXPERIMENTAL STUDIES}

12 specimens consisting of 3 series A, B and C each having 4 specimens of composite channel sections were tested. Cross sectional dimensions of channel sections considered was $170 * 100 \mathrm{~mm}, 250 * 150 \mathrm{~mm}$. Beam designations shown

\begin{tabular}{|c|c|c|}
\hline Series & Beam Designation & Term explanations \\
\hline \multirow{4}{*}{ A } & A $1 \mathrm{~N}$ & \multirow{12}{*}{$\begin{array}{l}“ \mathrm{~A} "=1.2 \mathrm{~mm} \text { Thick Steel } \\
" \mathrm{~B} "=1.5 \mathrm{~mm} \text { Thick Steel } \\
\text { "C" }=2.0 \mathrm{~mm} \text { Thick Steel } \\
" 1 "=170^{*} 100 \mathrm{~mm} \\
“ 2 "=250^{*} 150 \mathrm{~mm} \\
\text { "N"= Normal Concrete } \\
\text { "L" = Light Weight } \\
\text { Concrete }\end{array}$} \\
\hline & A $1 \mathrm{~L}$ & \\
\hline & A $2 \mathrm{~N}$ & \\
\hline & A $2 \mathrm{~L}$ & \\
\hline \multirow{4}{*}{ B } & B $1 \mathrm{~N}$ & \\
\hline & B $1 \mathrm{~L}$ & \\
\hline & B $2 \mathrm{~N}$ & \\
\hline & B 2 L & \\
\hline \multirow{4}{*}{$\mathrm{C}$} & $\mathrm{C} 1 \mathrm{~N}$ & \\
\hline & C $1 \mathrm{~L}$ & \\
\hline & $\mathrm{C} 2 \mathrm{~N}$ & \\
\hline & $\mathrm{C} 2 \mathrm{~L}$ & \\
\hline
\end{tabular}
in Table 1.

Table 1: Beam designation

\subsection{Materials Used}

\section{A. Steel sheet}

To know the properties, steel sheet out of which the channel sections were prepared, samples were taken and tested as per Indian Standards in "Civil Aid Techno-Clinic", Kamakshipalya, Bangalore. Three thicknesses of $1.2 \mathrm{~mm}$, $1.5 \mathrm{~mm}$ and $2.0 \mathrm{~mm}$ were tested and shown in Table 2 .

Table 2: Properties of steel

\begin{tabular}{|l|l|l|l|}
\hline $\begin{array}{l}\text { Specimen } \\
\text { thickness }\end{array}$ & $\begin{array}{l}\text { Ultimate } \\
\text { tensile } \\
\text { Strength } \\
\mathrm{N} / \mathrm{mm}^{2}\end{array}$ & $\begin{array}{l}\text { Yield } \\
\text { stress } \\
\mathrm{N} / \mathrm{mm}^{2}\end{array}$ & $\begin{array}{l}\text { Elongation in } \\
\%\end{array}$ \\
\hline $1.2 \mathrm{~mm}$ & 361 & 218 & 51.7 \\
\hline $1.5 \mathrm{~mm}$ & 419 & 251 & 50.0 \\
\hline $2.0 \mathrm{~mm}$ & 342 & 205.2 & 40.0 \\
\hline
\end{tabular}




\section{B. Concrete}

Two different types of concrete used as infill for channel sections were M30 grade and Light Weight concrete

Materials used to obtain the M30 Grade concrete are 53 Grade Ordinary Portland cement, coarse aggregates of $12.5 \mathrm{~mm}$ down size, Natural river sand and Potable water. The ratio adopted was 1: 1.709: 2.7 and water to cement ratio is 0.45

For preparation of Light Weight Concrete (Epoxy Polystyrene Concrete) constituent materials 53 Grade Ordinary Portland cement, Natural river sand, EPS Beads of size $1.2 \mathrm{~mm}$ to $4.0 \mathrm{~mm}$ and Potable water were used.

The ratio of cement: sand adopted was 1:1.35, water to cement ratio 0.45 . In this investigation we have replaced the $5 \%$ of fine aggregates by EPS beads. It was observed that, handling of EPS beads was very difficult and it caused problems in hand mixing as shown in Plate 3. By using the above mentioned ratios, both M30 grade and light weight concrete were prepared. Standard cubes of size $150 * 150 * 150 \mathrm{~mm}$ were cast from the mix used for preparation of composite beams.

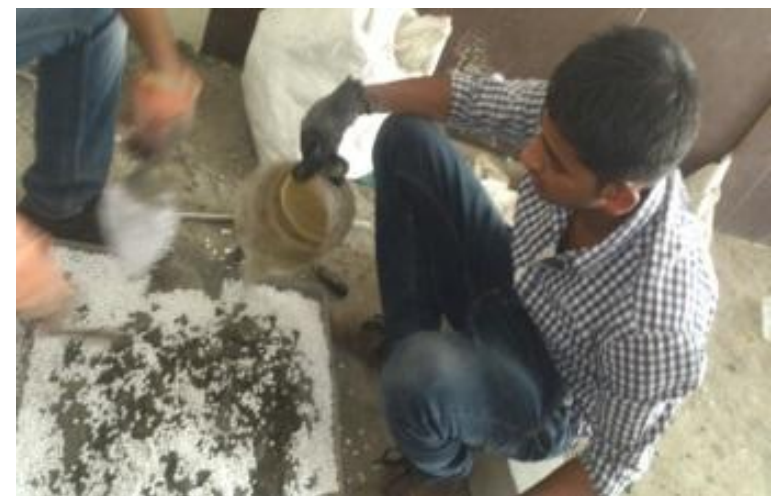

Plate 3: Trial mixing of light weight concrete by hand

The average values of 28 days compressive strength of cubes obtained are

1. M 30 grade cubes $-43 \mathrm{MPa}$

2. Light weight cubes $-8 \mathrm{MPa}$

\subsection{Procedure to Obtain Test Specimens}

Steel sheets of thicknesses $1.2 \mathrm{~mm}, 1.5 \mathrm{~mm}$ and $2.0 \mathrm{~mm}$ were cut to the required dimensions Using press brake method, these specimens were fabricated by press braking method in "JOY INDUSTRIES, PEENYA, BENGALURU" as shown in Plate 4

All the channel sections are provided with shear connectors. Bar type shear connectors are used. Bar type shear connectors are obtained from the left over pieces from the same steel sheet which was used in making the channel sections. The size of bar type shear connectors used in this investigation is $10 * 30 \mathrm{~mm}$ size. These shear connectors are welded to the three sides of the channel sections as shown in Plate 5. Shear connectors are welded at a spacing of $150 \mathrm{~mm}$ centre to centre for $600 \mathrm{~mm}$ length at both the ends and $300 \mathrm{~mm}$ spacing at the centre portion of the beam.

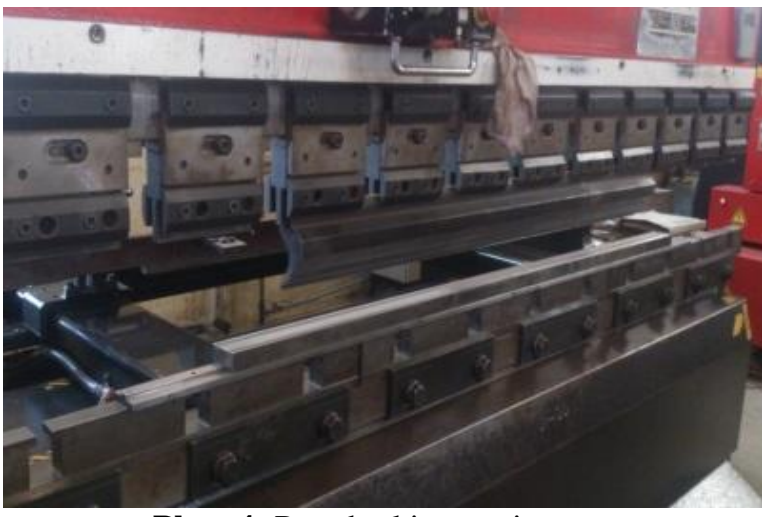

Plate 4: Pressbraking equipment

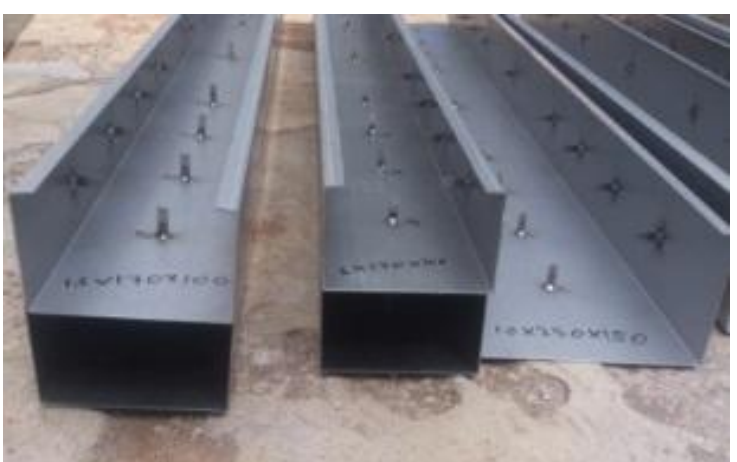

Plate 5: Channel sections with shear connectors

After the fabrication of channels sections with shear connectors, the specimens were painted with primer paint only to the exteriors of the channels sections as shown in Plate 6 and they are kept vertically for sun drying.

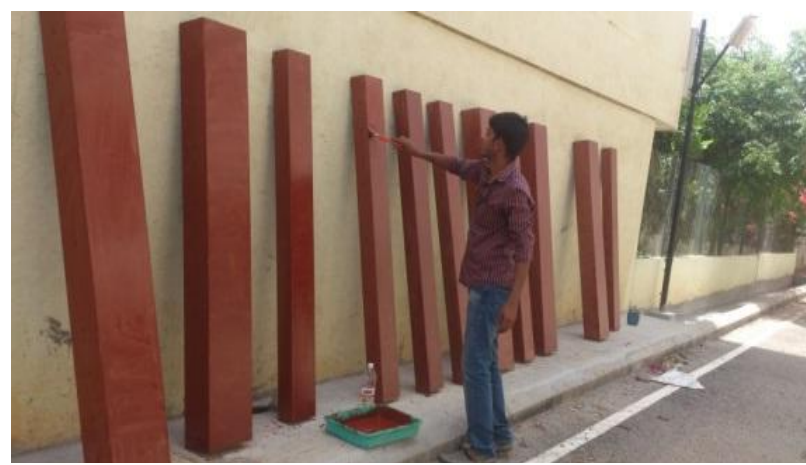

Plate 6: Exterior surface of the specimens is painted with primer

Concrete was mixed in a drum mixer of capacity $0.3 \mathrm{~m}^{3}$ and Concrete was poured to the open section of the beam and at the ends steel sheets were kept as form work. In Light Weight concrete batching process, at first cement, sand and water was mixed thoroughly and then after some time, EPS beads of required amount was added slowly and mixed as shown in Plate 7 and Plate 8. After 24 hours of casting, channel sections were covered with gunny bags and curing was done for 28 days as shown in Plate 9.From the same mix Standard cubes of size $150 * 150 * 150 \mathrm{~mm}$ were cast to know the compressive strength of the concrete. Both M30 grade and light weight concrete cubes of 3 numbers each were cast and tested for 28 days compressive strength as shown in Plate 10. 

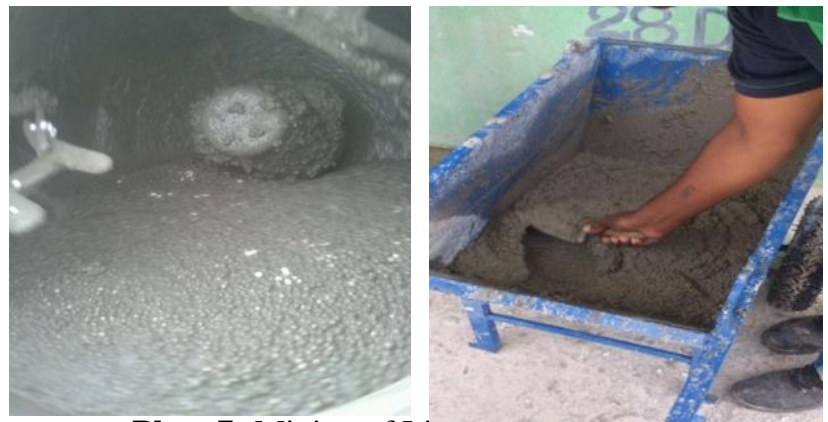

Plate 7: Mixing of Ligitl wergit cuinctel

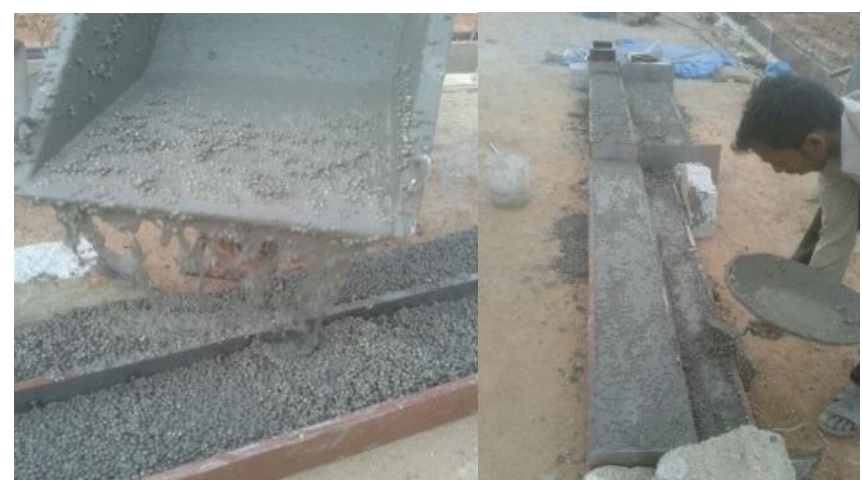

Plate 8: Casting and finishing of Light weight concrete
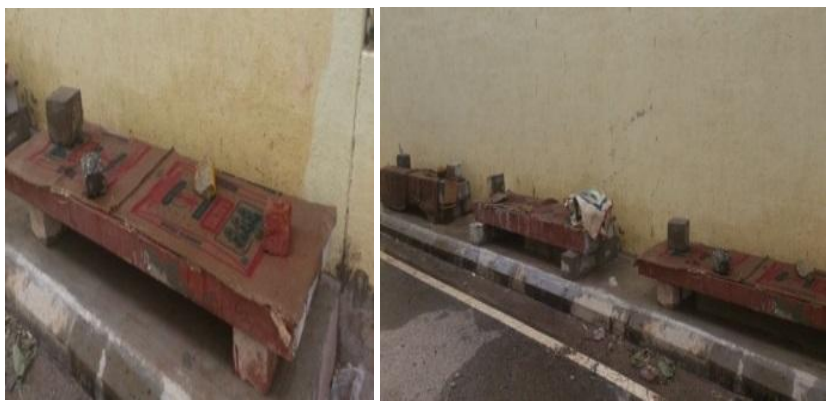

Plate 9: Beams are covered with gunny bags and cured for 28 days

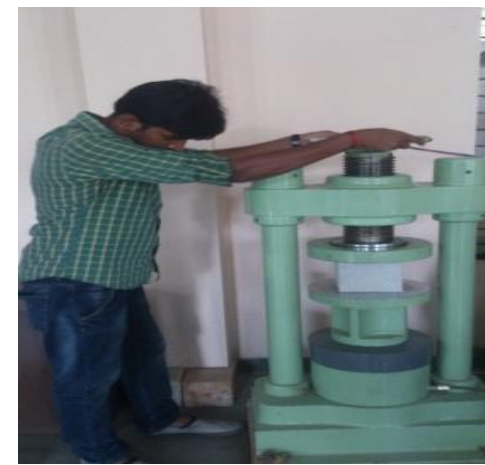

Plate 10: Cubes tested in compressive testing machine for 28 days strength.

\subsection{Testing procedure}

A precession loading frame of 100 tonnes capacity was used in testing the beams. The load cell which is used was 20 tonnes capacity. Two roller supports were provided $50 \mathrm{~mm}$ apart from the ends of the beam. Two point loads was applied transversely for channel sections ata/d ratio of5. $(\mathrm{a}=$ distance from support to the point of loading,

$\mathrm{d}=$ depth of the beam)

The loading arrangement for beams of cross sections $250 *$ $150 \mathrm{~mm}$ and $170 * 100 \mathrm{~mm}$ beams are shown figure $2 \mathrm{a}, 2 \mathrm{~b}$ Figure $2 \mathrm{a} .250 * 150 \mathrm{~mm}$ :

$$
200
$$

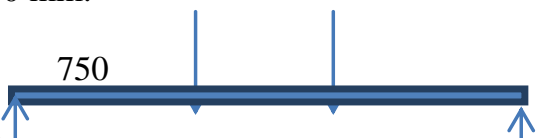

Figure 2b. $170 * 100 \mathrm{~mm}$ :

Sensitivity $0.1 \mathrm{~mm}$ LVDT is fixed at the centre of the beam to note down the deflection. Load cell of capacity $200 \mathrm{kN}$ was used. The loading was applied at the rate of $10 \mathrm{kN} / \mathrm{sec}$. Strain gauges of $350 \Omega, 1.9$ gauge factor was used. In the mid span of the beam strain gauges were placed at the top, middle and bottom to note down the strain values. The arrangement of the specimen on the loading frame is as shown in Plate 11 and the arrangements of the strain gauges on the specimens are shown in plate 12 .

Load was applied gradually using Hydraulic jack in increment till failure of the specimens. The behaviour of the beams was keenly observed throughout the loading range till the specimen failed. Load Deflection curves for each beam were obtained from the software and strain values were also noted down in excel sheets by the software for each loading. Also the appearance of separation, buckling, propagation of cracks and slip were observed and recorded.

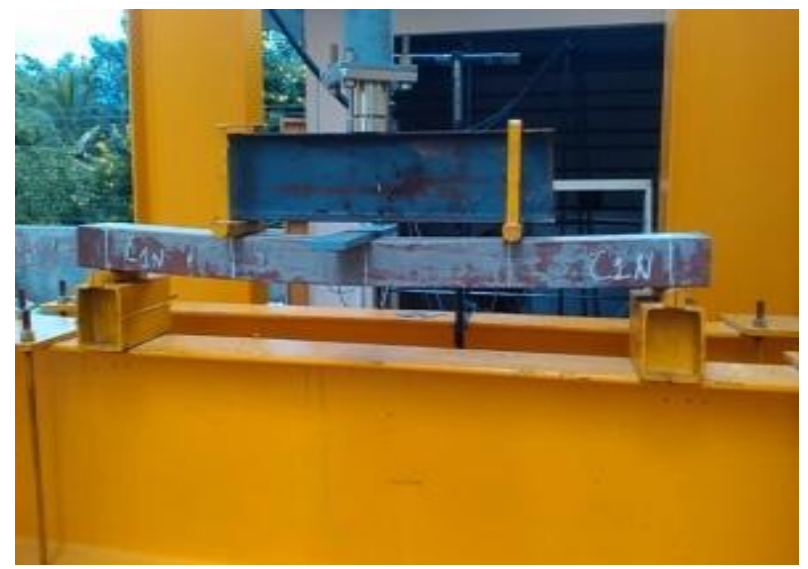

Plate 11: Arrangements of specimen on the loading frame.

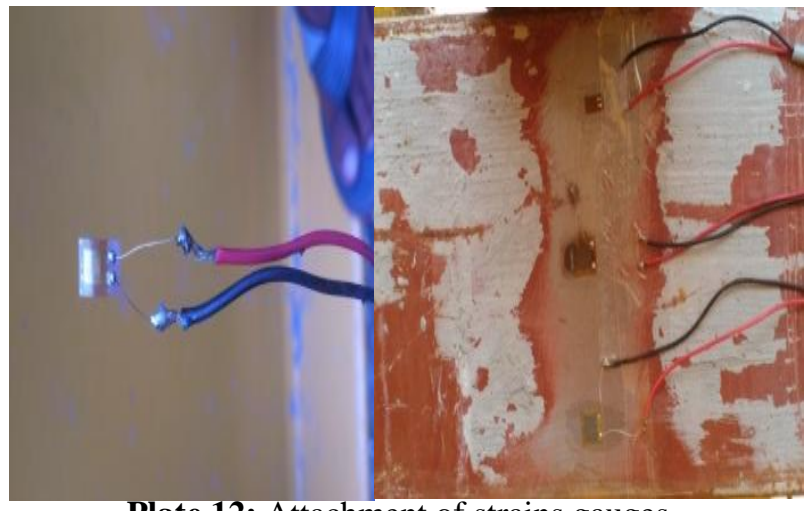

Plate 12: Attachment of strains gauges. 


\section{RESULTS AND DISCUSSIONS}

\subsection{Load-Mid Span Deflection Behaviour Of Beams}

From the figure 3 to figure 6 , we can make out that load carrying capacity of the beams (both normal concrete and light weight concrete as infill) made of $2.0 \mathrm{~mm}$ thick steel has higher. But, when the beams are infilled with light weight, the deflection is more and the ductility property increases as the grade of the concrete decreases Beams which are filled with normal concrete are much stiffer than that of beams filled with light weight concrete

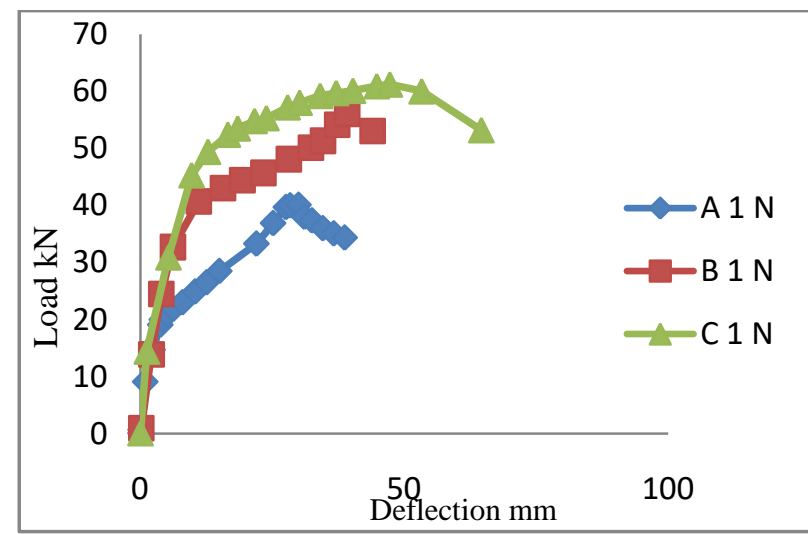

Figure 3: Load Deflection behaviour of A1N, B1N and $\mathrm{C} 1 \mathrm{~N}$ beams

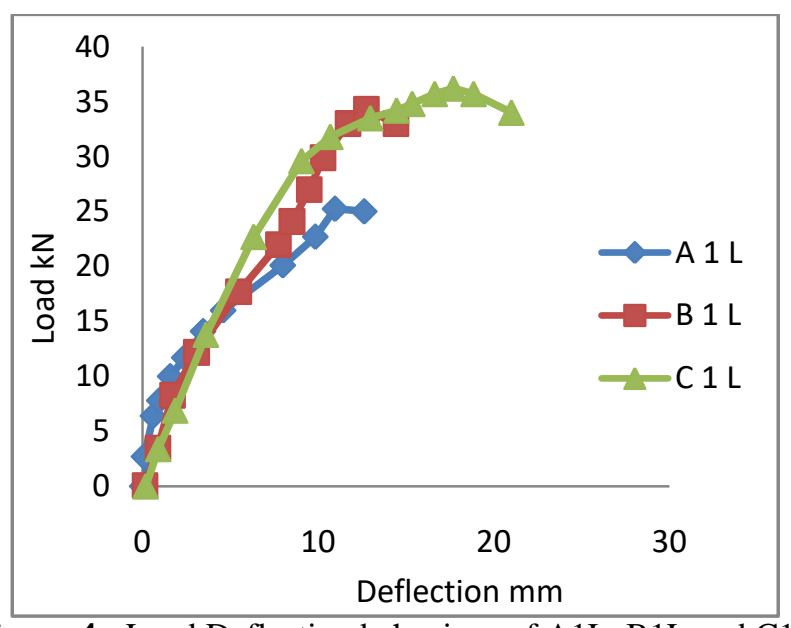

Figure 4: Load Deflection behaviour of A1L, B1L and C1L beams

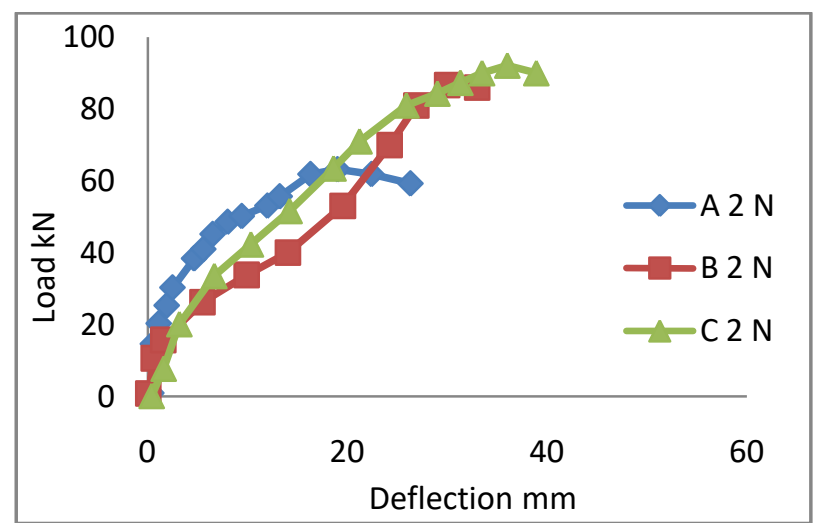

Figure 5: Load Deflection behaviour of A2N, B2N and $\mathrm{C} 2 \mathrm{~N}$ beams

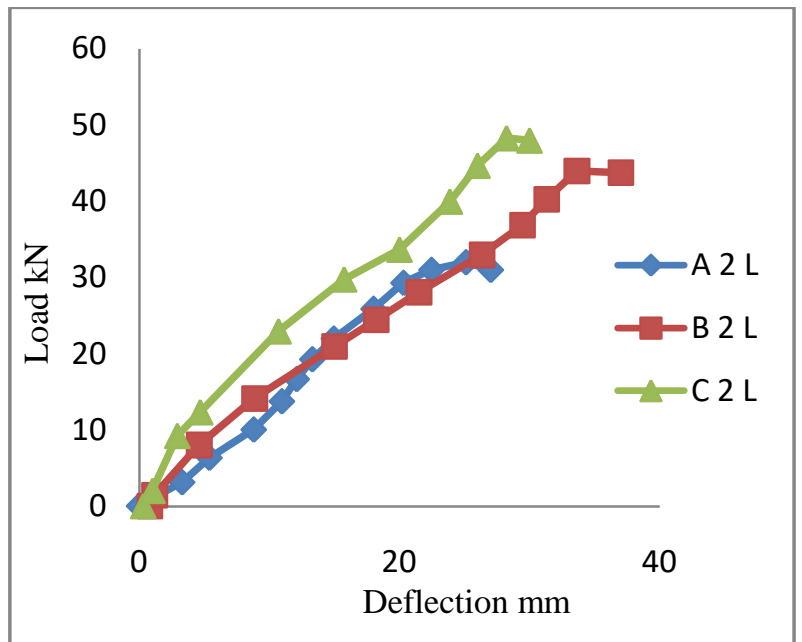

Figure 6: Load Deflection behaviour of A2L, B2L and C2L beams

\subsection{Ductility Index}

Ductility index is the ratio of ultimate deflection to the deflection at the yield.Beams of cross section $170 * 100 \mathrm{~mm}$ infilled with normal concrete with $1.2 \mathrm{~mm}$ thickness of steel sheet has greater ductility index when compared with beams of $1.5 \mathrm{~mm}$ and $2.0 \mathrm{~mm}$ thicknesses. But in cross section $250 * 150 \mathrm{~mm}$ beams infilled with normal concrete made of $2.0 \mathrm{~mm}$ steel sheet has greater ductility index property as shown in Table 3 and figure 7. But in light weight infilled beams, both the cross sections are showing greater ductility index property when compared with beams infilled with normal concrete.

Table 3: Ductility index of beams

\begin{tabular}{|l|l|l|l|l|}
\hline $\begin{array}{l}\text { Serie } \\
\mathrm{s}\end{array}$ & $\begin{array}{l}\text { Beam } \\
\text { Designatio } \\
\mathrm{n}\end{array}$ & $\begin{array}{l}\text { Ultimate } \\
\text { Deflectio } \\
\mathrm{n} \mathrm{mm}\end{array}$ & $\begin{array}{l}\text { Deflectio } \\
\text { n @ yield } \\
\mathrm{mm}\end{array}$ & $\begin{array}{l}\text { Ductilit } \\
\text { y index }\end{array}$ \\
\hline \multirow{4}{*}{$\mathrm{A}$} & A1N & 83.01 & 16.5 & 5.03 \\
\cline { 2 - 5 } & A1L & 72.30 & 6.14 & 11.7 \\
\cline { 2 - 5 } & A2N & 32.49 & 12.9 & 2.51 \\
\cline { 2 - 5 } & A2L & 94.30 & 11.1 & 8.57 \\
\hline \multirow{4}{*}{ B } & B1N & 84.61 & 23.4 & 3.61 \\
\cline { 2 - 5 } & B1L & 68.71 & 8.57 & 8.01 \\
\cline { 2 - 5 } & B2N & 38.06 & 10.3 & 2.33 \\
\cline { 2 - 5 } & B2L & 101.5 & 20.5 & 4.95 \\
\hline \multirow{4}{*}{ C } & C1N & 88.05 & 15.3 & 2.93 \\
\cline { 2 - 5 } & C1L & 88.56 & 11.6 & 7.63 \\
\cline { 2 - 5 } & C2N & 67.65 & 21.4 & 3.16 \\
\cline { 2 - 5 } & C2L & 101.9 & 16.4 & 6.21 \\
\hline
\end{tabular}




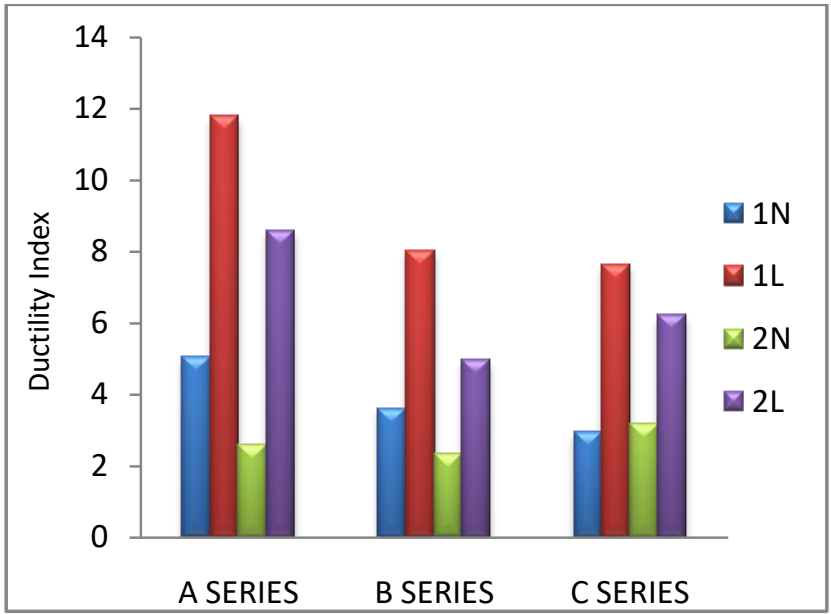

Figure 7: Ductility index for all series of beams

\subsection{Ultimate Loads}

On an average ratio of $\mathrm{P}_{\exp } / \mathrm{P}$ Theo for beams infilled with normal concrete was around 1.5 as shown in Table 4 and in the case of beams infilled with light weight concrete the average ratio was found to be 1.10 shown in Figure 8 and thus, experimented values are closer to the theoretical calculated values in case of beams infilled with light weight concrete.

On an average, beams infilled with M30 grade concrete will have their load carrying capacity $42 \%$ greater than beams infilled with light weight concrete. On average beams of thicknesses $1.5 \mathrm{~mm}$ and $2.0 \mathrm{~mm}$ are having $32 \%$ greater load carrying capacity than beam of thickness $1.2 \mathrm{~mm}$ and they are shown in Figure 9.

Table 4: Comparison of Experimental and Theoretical Ultimate Loads

\begin{tabular}{|l|l|l|l|l|}
\hline No. & $\begin{array}{l}\text { Beam } \\
\text { Designation }\end{array}$ & $\begin{array}{l}\text { Theoretical } \\
\text { loads } \\
\mathrm{kN}\end{array}$ & $\begin{array}{l}\text { Experimental } \\
\text { loads kN }\end{array}$ & $\begin{array}{l}\mathrm{P}_{\text {exp }} / \\
\mathrm{P}_{\text {Theo }}\end{array}$ \\
\hline \multirow{4}{*}{ A } & A 1 N & 27.65 & 40.1 & 1.45 \\
\cline { 2 - 5 } & A 1 L & 20.44 & 25.24 & 1.23 \\
\cline { 2 - 5 } & A 2 N & 37.9 & 63.24 & 1.6 \\
\hline & A 2 L & 31.8 & 32.8 & 1.03 \\
\hline \multirow{4}{*}{ B } & B 1 N & 34.2 & 56.24 & 1.6 \\
\cline { 2 - 5 } & B 1 L & 27.8 & 34.30 & 1.22 \\
\cline { 2 - 5 } & B 2 N & 52.9 & 86.66 & 1.61 \\
\cline { 2 - 5 } & B 2 L & 42.7 & 44.3 & 1.03 \\
\hline \multirow{4}{*}{ C } & C 1 N & 39.47 & 61.2 & 1.55 \\
\cline { 2 - 5 } & C 1 L & 31.88 & 36.2 & 1.13 \\
\cline { 2 - 5 } & C 2 N & 61.05 & 92.1 & 1.50 \\
\cline { 2 - 5 } & C 2 L & 49.29 & 48.3 & 0.97 \\
\hline
\end{tabular}

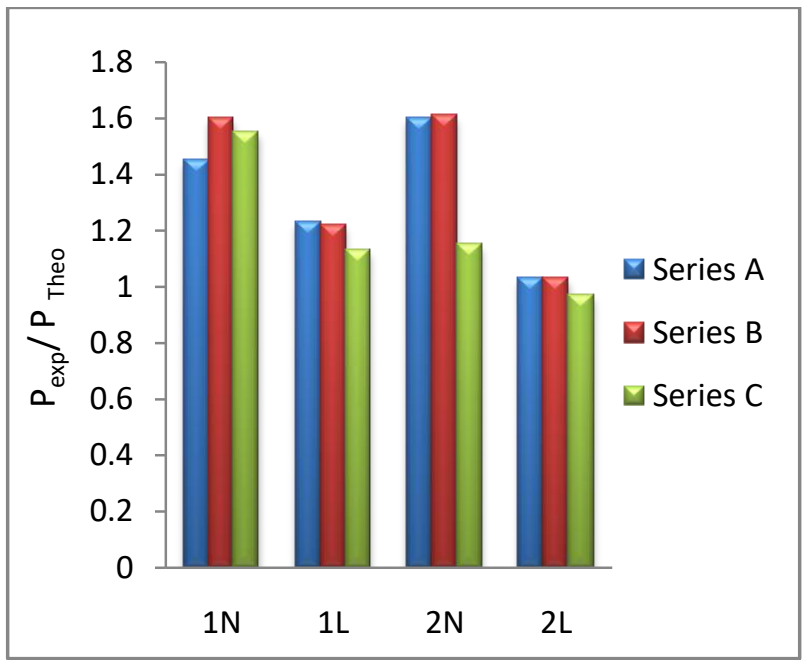

Figure 8: Ratio of $\mathrm{P}_{\exp } / \mathrm{P}_{\text {Theo }}$

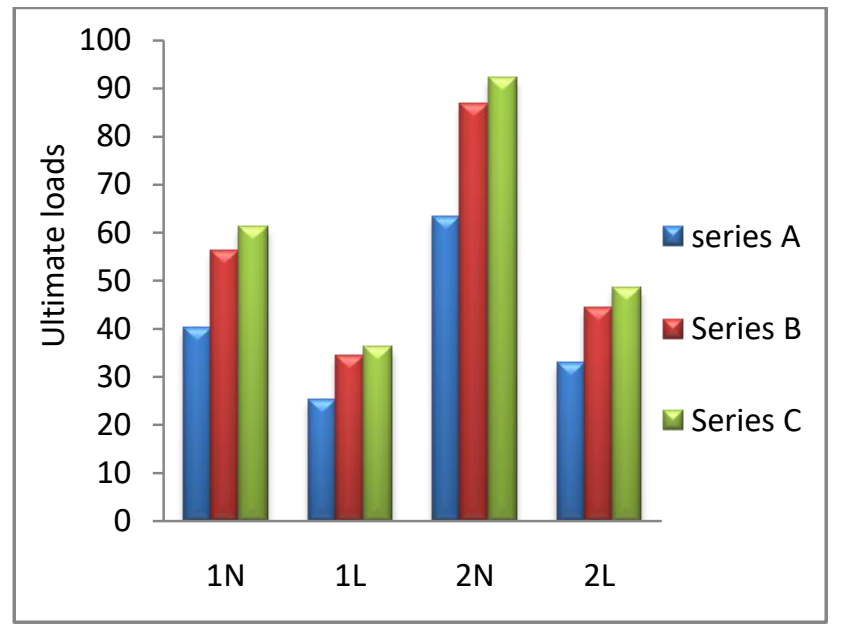

Figure 9: Experimented ultimate loads for all series of beams

\subsection{Strength To Weight Ratio}

Strength to weight ratio is the ratio of load carrying capacity to the total weight of the beam and it is given in the Table 5 . Comparisons of strength to weight ratios of beams with 1.2, 1.5 and $2.0 \mathrm{~mm}$ thick steel are given in Figure 10.We can observe that beams of cross section of $170 * 100 \mathrm{~mm}$ beams are having higher strength to weight ratios when compared to beams of cross section $250 * 150 \mathrm{~mm}$. it is observed that strength to weight ratio increased as the thickness and grade of the concrete increased.

Table 5: Strength to weight ratio calculations

\begin{tabular}{|c|c|c|c|c|c|c|}
\hline $\begin{array}{l}\text { Seri } \\
\text { es }\end{array}$ & $\begin{array}{l}\text { Beam } \\
\text { Designa } \\
\text { tion }\end{array}$ & $\begin{array}{l}\text { Wei } \\
\text { ght } \\
\text { of } \\
\text { steel } \\
\mathrm{Kg}\end{array}$ & $\begin{array}{l}\text { Weig } \\
\text { ht of } \\
\text { concr } \\
\text { ete } \\
\mathrm{Kg}\end{array}$ & $\begin{array}{l}\text { Tota } \\
\text { l } \\
\text { weig } \\
\text { ht of } \\
\text { bea } \\
\mathrm{m} \\
\mathrm{Kg} \\
\text { (w) }\end{array}$ & $\begin{array}{l}\text { Stren } \\
\text { gth of } \\
\text { beam } \\
\mathrm{Kg} \\
\left(\mathrm{P}_{\text {exp }}\right)\end{array}$ & $\begin{array}{l}\text { Stren } \\
\text { gth to } \\
\text { Weig } \\
\text { ht } \\
\text { ratio } \\
\mathrm{P}_{\text {exp }} \\
/ \mathrm{w}\end{array}$ \\
\hline \multirow[t]{2}{*}{ A } & A1N & 8.21 & 62.7 & $\begin{array}{l}71.0 \\
3\end{array}$ & 393.7 & 5.57 \\
\hline & A1L & 8.21 & 41.2 & 49.4 & 249.1 & 5.48 \\
\hline
\end{tabular}




\begin{tabular}{|l|l|l|l|l|l|l|}
\hline \multirow{4}{*}{} & & & & 8 & & \\
\cline { 2 - 7 } & A2N & 11.9 & 140. & $\begin{array}{l}152 . \\
0\end{array}$ & 624.1 & 4.10 \\
\cline { 2 - 7 } & A2L & 11.9 & 92.0 & $\begin{array}{l}104 . \\
0\end{array}$ & 323.7 & 3.11 \\
\hline \multirow{4}{*}{ B } & B1N & 10.2 & 62.1 & $\begin{array}{l}72.3 \\
7\end{array}$ & 555.0 & 7.67 \\
\cline { 2 - 7 } & B1L & 10.2 & 40.8 & $\begin{array}{l}51.0 \\
8\end{array}$ & 338.5 & 6.62 \\
\cline { 2 - 7 } & B2N & 14.9 & 139. & $\begin{array}{l}154 . \\
1\end{array}$ & 855.3 & 5.54 \\
\hline & B2L & 14.9 & 91.4 & $\begin{array}{l}106 . \\
4\end{array}$ & 437.2 & 4.10 \\
\hline \multirow{3}{*}{ C } & C1N & 13.5 & 61.0 & $\begin{array}{l}74.7 \\
8\end{array}$ & 604.0 & 8.07 \\
\cline { 2 - 7 } & C1L & 13.6 & 40.1 & $\begin{array}{l}54.0 \\
1\end{array}$ & 357.2 & 6.61 \\
\cline { 2 - 7 } & C2N & 19.9 & 137. & $\begin{array}{l}157 . \\
6\end{array}$ & 909.0 & 5.76 \\
\cline { 2 - 7 } & C2L & 19.9 & 90.5 & $\begin{array}{l}110 . \\
4\end{array}$ & 476.7 & 4.31 \\
\hline
\end{tabular}

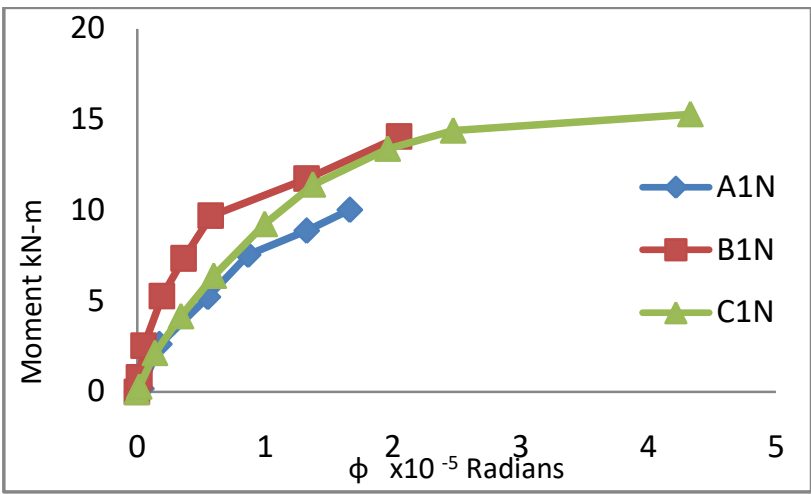

Figure 11: Moment curvature curve for beams A1N, B1N, $\mathrm{C} 1 \mathrm{~N}$

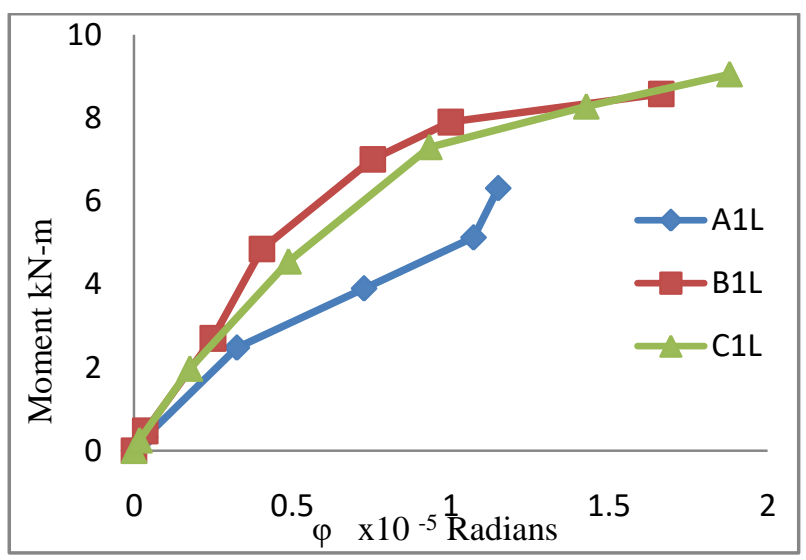

Figure 12: Moment curvature curve for beams A1L, B1L, C1L

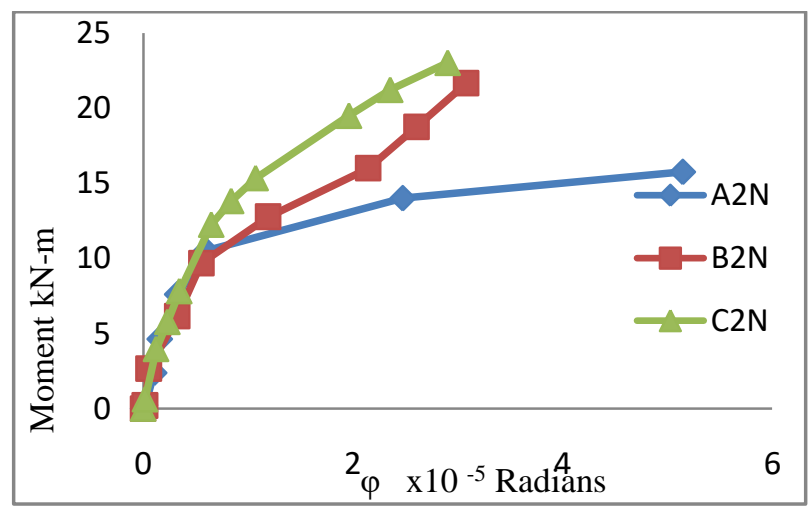

Figure 13: Moment curvature curve for beams A2N, B2N, $\mathrm{C} 2 \mathrm{~N}$ this behaviour was observed in both the beams of cross sections $170 * 100 \mathrm{~mm}$ and $250 * 150 \mathrm{~mm}$. But beams of cross section $250 * 150 \mathrm{~mm}$ size had lesser rotation capacity when compared to beams of cross section $170^{*} 100 \mathrm{~mm}$. When we consider beams of same cross sections but different infill, for a particular moment, light weight concrete infilled beams are having higher rotation capacity when compared with the beams infilled with normal concrete. But, in the ultimate loads, beams infilled with normal concrete had showed greater rotation capacity. From the Figure 11 to Figure 14, Moment carrying capacity of the beams will increase as the grade of the concrete increases and also increases with the increase in the thickness of the steel sheet. Rotation capacity of the beams was found to be higher in beams of cross section $170 * 100 \mathrm{~mm}$ when compared with beams of cross section $250 * 150 \mathrm{~mm}$.

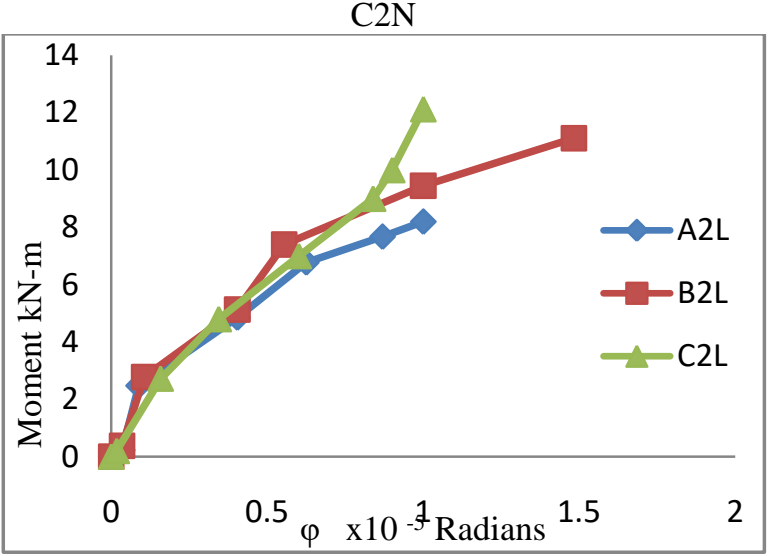

Figure 14: Moment curvature curve for beams A2L, B2L, $\mathrm{C} 2 \mathrm{~L}$ 


\section{FAILURE PATTERNS}

It was observed that there was local bucking at the centre of the sections in compression zone at the failure load. In composite sections infilled with light weight concrete the local buckling was in larger amount when compared with the composite beams infilled with M30 grade concrete as shown in Figure $12 \mathrm{a} \& 12 \mathrm{~b}$.

It was observed that the measured slip of concrete at the ends of the specimens was $20 \mathrm{~mm}$ in the sections infilled with M30 grade as shown in Plate 13, but there was no slip of concrete observed in the specimens infilled with light weight epoxy polystyrene concrete. But in the light weight composite specimens crushing of aggregate and concrete had happened.

Shear connectors had protruded out at the centre of the beams due to buckling and this was greatly observed only in the specimens of smaller sections as shown in plate $15 \mathrm{a} \&$ $15 \mathrm{~b}$ and crushing of concrete had happened at the centre of the specimens infilled with M30 grade concrete as shown in plate 14 .

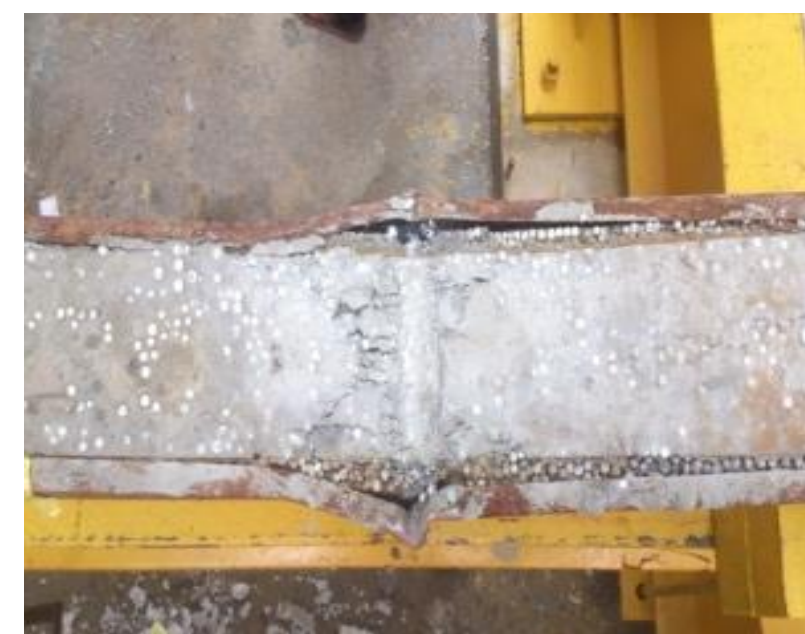

Plate 12a: Buckling of steel in compression zone in light weight concrete infilled beam.

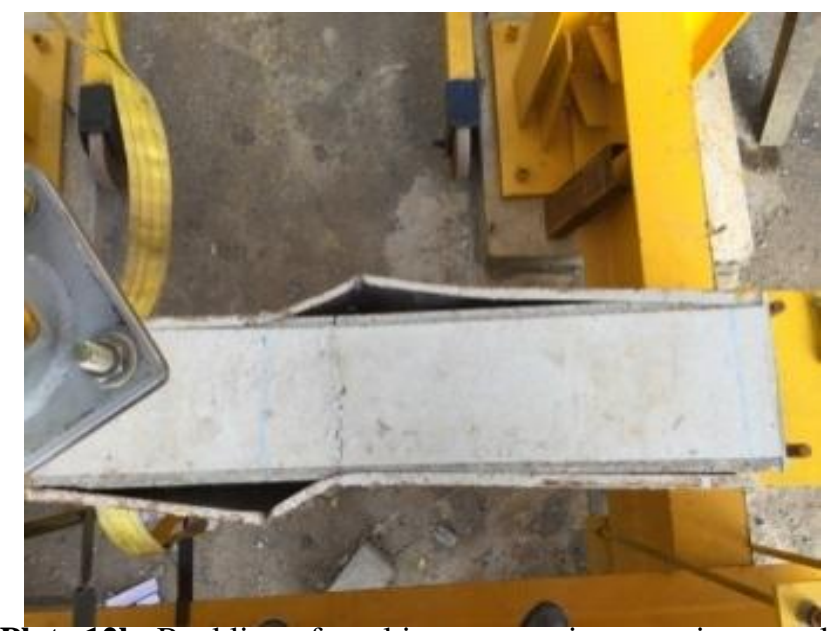

Plate 12b: Buckling of steel in compression zone in normal concrete infilled beam.

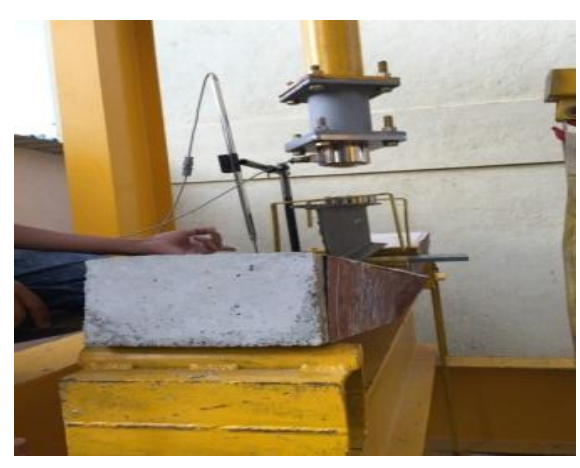

concrete at the ends

Plate 13: Slip of

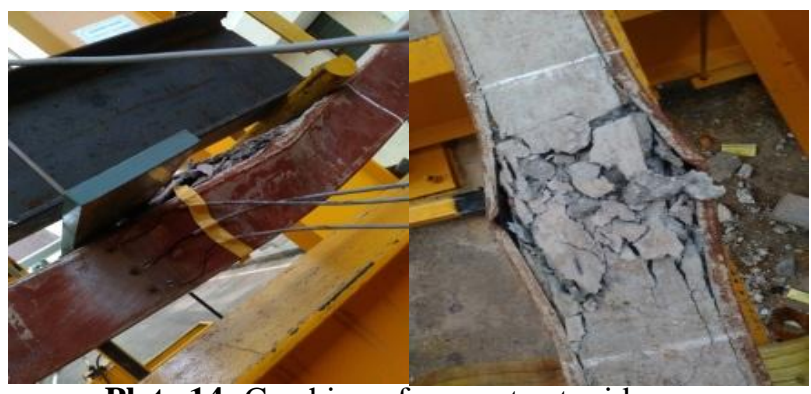

Plate 14: Crushing of concrete at mid span

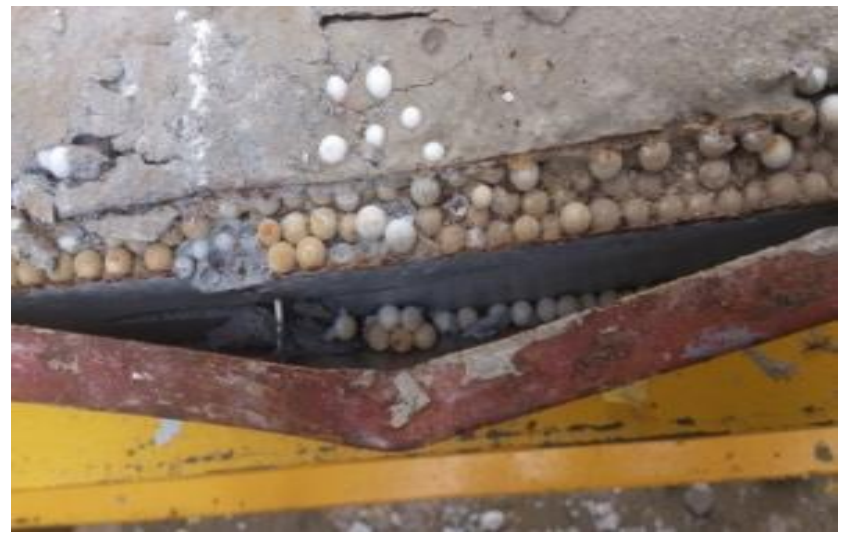

Plate 15a:Protrude of shear connectors from the concrete in light weight concrete infilled beams

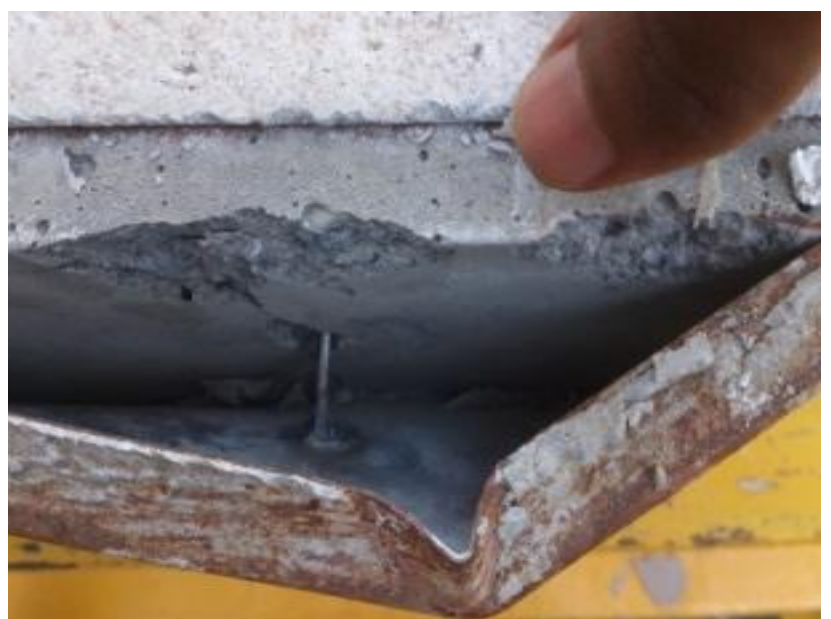

Plate 15b: Protrude of shear connectors from the concrete in normal concrete infilled beams 


\section{CONCLUSIONS}

[1]. On an average, ratios of Pexp/ $\mathrm{P}$ Theo for the beams infilled with M30 grade concrete and light weight concrete were 1.5 and 1.1 respectively. In beams infilled with light weight concrete, experimented values were closer to the theoretical values.

[2]. On an average, beams infilled with M30 grade concrete have load carrying capacity $42 \%$ greater than beams infilled with light weight concrete.

[3]. Beams of thicknesses $1.5 \mathrm{~mm}$ and $2.0 \mathrm{~mm}$ were having $32 \%$ and $30 \%$ greater load carrying capacity and strength to weight ratios respectively than beams of $1.2 \mathrm{~mm}$ thick steel beams (in both the cases of beams infilled with light weight concrete and normal concrete).

[4]. Ductility index of the beams infilled with light weight concrete had $70 \%$ greater when compared with beams infilled with normal concrete.

[5]. Load carrying capacity and Moment carrying capacity of the beams increases as the thickness of steel sheet and the grade of the concrete increases.

[6]. Rotation capacities of the beams were found to be higher in beams of cross section $170 * 100 \mathrm{~mm}$ when compared with beams of cross section $250 * 150 \mathrm{~mm}$.

[7]. Failure patterns observed were buckling of steel, slip of concrete andcrushing of concrete.

\section{REFERENCES}

[1]. Abdulkadirkan and RamazanDemirboga, (2007), "Effect of cement and EPS Beads ratios on Compressive Strength and Density of Light Weight Concrete", Construction programme, Department of Civil Engineering, Ataturk University, 25240 Erzurum, Turkey.

[2]. Ali SardrMomtazi, AlimohamadMirghozarlangrudi, Akbar KhodaparastHaggi and HadiRasmiAtigh., (2010)“ Durability of Lightweight Concrete containing EPS in Salty Exposure Conditions " Fourth National Congress of Civil Engineering, Iran, University of Tehran, 1387

[3]. Arivalagan and Kandasamy, (2009) “ Energy Absorption Capacity of Composite Beams" , Journal of Engineering Science and Technology Review 2(1), page $145-150$

[4]. Abhijitmandlik, TarunSarthakSood, Shekharkarade, SangramNaikAmrutaKulkarani (2013), "light Weight Concrete Using EPS", SaitriPhule Pune University. Pune

[5]. Dr.Bhaskar Desai .V, Mr. A. Sathyam,(2014), “ Some Studies on Strength Properties of light Weight Aggregate Concrete". JNTUA College of Engineering, Anantapuram, AP, India.

[6]. Herki B. A, J M Khatib and E.M Negim, (2013), "Light Weight Concrete Made from Waste Polystyrene and Fly Ash". University of Wolverhampton, Wolverhampton, WVI, UK.

[7]. Idawati Ismail, A. Aziz Saim, Abdlatifsaleh. (2003) "Properties of hardened Concrete Bricks Containing Expanded Polystyrene Beads", Department of
Structures and Materials, University Teknologi, Malaysia, Johar, Malaysia.

[8]. Karhika R, S. Saravanan. Dr. R. Angeline Prabhavathy, ( 2015 ), “ Behaviour OF Cold Formed Steel Frames With Cement Bonded Particle Board Infill", Journal of Recent Research in Engineering and technology;2349-2252, Volume 2. Issue 4 April

[9]. Lin C. Y ,(1998) "Axial Capacity of Concrete Infilled Cold-formed Steel Columns", International Specialty Conference on Cold-Formed Steel Structures,Paper2

[10]. Miled K, K. Sab, R. Le Roy,.(2006), “ Particle Size Effect on EPS Light Weight Concrete Compressive Strength : Experimental Investigation and modelling”, Mechanics Of Materials, BD Lefebvre, 75732 Paris 15, France.

[11]. NoureddineFerhoune, (2014) "Experimental Behaviour Of Cold-Formed Steel Welded Tube Filled With Concrete made of Crushed Crystallized Slag Subjected to Eccentric Loading" Thin-Walled Structures, Volume 80, page 159-166

[12]. Rajeshkumar B, Anil Kumar Patidar and Helen Santhi. M, (2013) "FE Analysis of Concrete Filled Cold Formed Steel Sections Using ANSYS”, Vol 3, January-June, Page 11-18,@ Research Science press, India

[13]. Setiawan. A and I. Hidayat, (2013) "Experimental Study On Epoxy Polystyrene as a Partial Substitute Of Fine Aggregate of Concrete Mixture" , Bina Nasantara University, West Jakarta, Indonesia.

[14]. TengkuFitriani .L. Subhan (2006) "Light Weight High Strength Concrete with Expanded Polystyrene Beads". "MEKTEK" TAHUN VIII No.1 January.

[15]. ValsaIpe T, H Sharadabai, K Manjulavani and Merchant Mohd Zafar Iqbal, (2013) "Flexural Behaviour Of Cold Formed Steel Concrete Composite Beams", Steel and Composite Structures , Vol 14, No 2. page 105-120

[16]. ZaherKuhail, (2001) "Polystyrene Light Weight Concrete (Polyconcrete)", Civil Engineering Department, Islamic University, Gaza, Palestine.

[17]. IS: 800-2007; Code of Practice for General Construction in Steel

[18]. IS: 801-1987 (Reaffirmed1995): Code of Practice for use of cold formed light gauge steel structural member's in general building construction

\section{APPENDIX A}

Calculation of moment carrying capacity

- $\mathrm{d}=$ Depth of section $=100 \mathrm{~mm}$

- $l=$ Lip length $=20 \mathrm{~mm}$

- $\mathrm{b}=$ width of section $=170 \mathrm{~mm}$

- $\quad P_{B}=$ Bond force

- $b_{c}=$ width of the concrete $=167.6 \mathrm{~mm}$

- $\quad N_{c}$ and $N_{s}=N=$ Distance of neutral axis from the extreme compression face for concrete and steel respectively

- $\quad M=$ Moment carrying capacity of composite beams

- $\quad \mathrm{t}=$ thickness of steel, $\mathrm{mm}$

- $f_{y}=$ yield stress of the steel, $218 \mathrm{~N} / \mathrm{mm}^{2}$ 
- $f_{c k}=$ characteristic compressive strength of concrete. $\mathrm{N} / \mathrm{mm}^{2} \mathrm{f}_{\mathrm{c}}{ }^{\prime}=0.8 f_{c k}=34.4 \mathrm{~N} / \mathrm{mm}^{2}$

$\gamma=$ Reduction factor $=0.85-0.007\left(f_{c}^{\prime}-28\right)=0.8052$

$$
\begin{aligned}
P_{B} & =\text { Bond force } \\
& =\frac{0.85 \gamma f^{\prime}{ }_{c} b_{c} t f_{y}\left(2 d+b_{c}-2 l\right)}{0.85 \gamma f^{\prime}{ }_{c} b_{c}+4 t f_{y}}
\end{aligned}
$$$$
=66744.97383
$$

$N_{s}=\mathrm{N}=\frac{t f_{y}\left(2 d+b_{c}-2 l\right)-P_{B}}{4 t f_{y}}=16.914$

$\mathrm{M}=t f_{y}\left(d^{2}+d b_{c}-2 N^{2}\right) 0.425 \gamma^{2} N^{2} f^{\prime}{ }_{c}^{*} b_{c}-$

$t^{2} f_{y} l \quad=6160636.93$

$\frac{a}{d}$ Ratio $=5, \frac{a}{100}=5$

$\mathrm{P}_{\text {Theoretical }}=\frac{M * 2}{a}=\frac{M * 2}{500}=27.6 \mathrm{k} \mathrm{N}$

\section{BIOGRAPHIES}

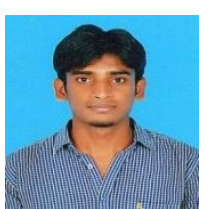

Mr. Naveen R K, completed BE in 2013 at Atria Institute of Engineering, Bangalore. M.Tech in Sri Venkateshwara College of Engineering in2015Bengaluru.India.

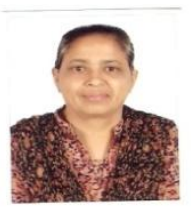

Dr.ValsaIpe TBE, M.Tech, Phd Professor, Faculty of Civil Engineering, MS Ramaiah University Of Applied Science, Bengaluru, Karnataka, India. 